\title{
Kesulitan Siswa Kelas XI IPA SMA Negeri Palangka Raya Tahun Ajaran 2018/2019 Dalam Memahami Konsep Pengaruh Penambahan Ion Senama Terhadap Kelarutan
}

\author{
Martauli Sibarani*, Suandi Sidauruk, Mulawi \\ Program Studi Pendidikan Kimia, Universitas Palangka Raya, Indonesia \\ *Email: martauli57@gmail.com
}

\begin{abstract}
Abstrak
Pengaruh penambahan ion senama terhadap kelarutan adalah salah satu dari pokok bahasan dalam mata pelajaran kimia kelas XI SMA dengan sub bab utama hasil kali kelarutan. Penelitian ini bertujuan untuk mendeskripsikan kesulitan siswa kelas XI IPA SMA Negeri di Kota Palangka Raya Tahun Ajaran 2018/2019 dalam memahami konsep pengaruh penambahan ion senama terhadap kelarutan.

Penelitian ini termasuk dalam penelitian deskriptif dengan pendekatan kuantitatif. Subjek penelitian ini melibatkan 190 siswa dari tiga sekolah yang masing-masing di ambil sebanyak dua kelas. Teknik pengambilan data dilakukan dengan TPKIS menggunakan intrumen tes uraian yang terdiri dari empat butir soal dengan tiga indicator. Didukung dengan sesi wawancara.

Hasil penelitian menunjukkan bahwa rerata kesulitan yang dialami siswa kelas XI IPA SMA Negeri di Kota Palangka Raya dalam memahami konsep pengaruh penambahan ion senama terhadap kelarutan sebesar 54,78\% Presentase kesulitan dalam setiap indikator meliputi; kesulitan siswa dalam pengaruh penambahan ion senama terhadap kelarutan sebesar 53,29\%, kesulitan siswa dalam pengaruh penambahan ion senama terhadap kelarutan asam dengan konsentrasi yang berbeda sebesar $54,21 \%$, dan kesulitan siswa dalam pengaruh penambahan ion senama dan air murni dalam larutan yang mudah larut sebesar $56,84 \%$.
\end{abstract}

Kata Kunci: Kesulitan, Ion Senama, Uraian 


\section{Pendahuluan}

Ilmu kimia merupakan cabang dari Ilmu Pengetahuan Alam (IPA) yang mengkaji zat dari segi sifat, komposisi, struktur, ikatan, perubahan dan pembuatannya, serta perubahan energi yang terlibat. Dari hasil survei awal yang dilakukan terhadap siswa kelas XI IPA SMA Negeri 2 Palangka Raya, diketahui bahwa pemahaman konsep siswa tentang efek penambahan ion senama terhadap kelarutan masih tergolong rendah dan masih mengalami kesulitan pada penyelesaian kelarutan. Hal ini disebabkan sebagian besar siswa kesulitan dalam menentukan jumlah mol dalam suatu reaksi. Kenyataan ini didukung oleh hasil penelitian Viyandari, dkk (2012), menunjukkan bahwa siswa SMA yang mengalami kesulitan dalam memahami pengaruh ion senama terhadap kelarutan sebesar 60,09\%, siswa masuk dalam kategori kesulitan.

Silabus kurikulum tingkat satuan pendidikan dan Kurikulum 2013 mata pelajaran kimia menunjukkan bahwa kelarutan dan hasil kali kelarutan dengan sub bab efek penambahan ion senama dipelajari di kelas XI semester ganjil Sekolah Menengah Atas (SMA). Konsep penambahan ion senama mempelajari tentang pengaruh efek penambahan ion senama dan perubahan kelarutan akibat ion senama. Hasil penelitian yang diharapkan memperkaya kajian ilmiah kimia, khususnya di kota Palangka Raya.

Hasil uji coba yang dilakukan diketahui bahwa siswa mengalami kesulitan dalam menyelesaikan soal-soal perhitungan ion senama yang mana sebagian siswa hanya mampu menuliskan persamaan reaksinya, untuk siswa yang lain masih banyak yang kesulitan dalam menjawab soal pada saat penentuan jumlah kelarutan masing-masing unsur. 
Kesulitan ini disebabkan oleh kurangnya pemahaman konsep siswa mengenai konsep kelarutan dan hasil kelarutan. Kesulitan siswa dalam memahami suatu konsep sangat mengganggu dalam membangun konsep baru. Berdasarkan latar belakang di atas, penulis tertarik untuk meneliti bagaimana kesulitan siswa dalam memahami konsep penambahan ion senama. Maka dilakukanlah penelitian tentang Kesulitan Siswa Kelas XI IPA SMA Negeri Palangka Raya Tahun Ajaran 2018/2019 Memahami Konsep Pengaruh Penambahan Ion Senama Terhadap Kelarutan.

Menurut (Sabri, 1995), kesulitan belajar yaitu kesukaran siswa dalam menerima atau menyerap pelajaran disekolah. Menurut Mirnayati (2011), kesulitan belajar dapat diartikan sebagai segala sesuatu yang menghalang-halangi atau memperlambat seorang siswa dalam mempelajari, memahami serta menguasai sesuatu. Adanya kesulitan belajar akan menimbulkan suatu keadaan dimana siswa tidak dapat belajar sebagaimana semestinya sehingga memiliki potensi belajar yang rendah. Menurut Suwarto (2013), kesulitan belajar juga dapat disebabkan karena mata pelajaran, hal ini mungkin berkenaan dengan keabstrakan konsep mata pelajarannya. Suatu mata pelajaran yang bersifat hierarki, yaitu dimulai dari konsep yang paling mudah hingga yang paling sukar akan memerlukan pemahaman yang berkesinambungan.

Fenomena kesulitan belajar seorang siswa biasanya tampak jelas dari menurunnya kinerja akademik atau prestasi belajarnya. Kesulitan belajar juga dapat dibuktikan dengan munculnya dengan kelainan perilaku (misbehavior) siswa seperti kesukaan berteriak-teriak didalam kelas, mengusik teman, berkelahi, sering tidak masuk sekolah dan sering minggat dari sekolah. Menurut Syah 
(2014), secara garis besar, faktor-faktor penyebab timbulnya kesulitan belajar terdiri atas dua macam yaitu : faktor internal siswa, yakni hal-hal atau keadaankeadaan yang dari dalam diri siswa sendiri dan faktor eksternal siswa, yakni halhal atau keadaan-keadaan yang datang dari luar diri siswa.

Menurut Huzaifah (2011), pemahaman diterjemahkan sebagai tingkat kemampuan yang mengharapkan seseorang mampu memahami arti atau konsep, situasi serta fakta yang diketahuinya. Pemahaman merupakan suatu proses berpikir dan belajar. Kemampuan berpikir tersebut meliputi kemampuan untuk membedakan, menjelaskan, memperkirakan, menafsirkan, memberikan contoh, menghubungkan, dan mendemontrasikan. Pemahaman konsep memiliki artian berupa kemampuan untuk menangkap dan menguasai lebih dalam lagi sejumlah fakta yang mempunyai keterkaitan dengan makna tertentu. Pemahaman konsep penting bagi siswa karena dengan memahami konsep dengan benar, maka siswa dapat menyerap, menguasai dan menyimpan materi yang dipelajarinya dalam jangka waktu yang lama.

Hasil penelitian yang dilakukan oleh Viyandari, dkk (2012) menunjukkan bahwa siswa SMA yang mengalami kesulitan dalam memahami pengaruh ion senama terhadap kelarutan sebesar $60,09 \%$. Siswa masih banyak mengalami miskonsepsi dalam memahami kesetimbangan reaksi akibat pengaruh ion senama, siswa mengetahui bahwa penambahan ion senama dalam larutan jenuh akan menyebabkan endapan, namun masih banyak yang mengalami miskonsepsi dengan soal tersebut. Siswa mengatakan bahwa semakin besar kecepatan zat untuk bereaksi. Siswa menyamakan antara kecepatan zat yang mudah melarut akibat penambahan konsentrasi dengan pengaruh ion senama dalam kelarutan. 
Siswa yang lain juga mengungkapkan bahwa ion senama akan terionisasi sempurna dalam larutan jenuh. Penelitian tentang pemahaman konsep terhadap pokok bahasan menentukan Kelarutan Dalam Ion Senama telah dilakukan oleh Arianto, dkk (2012). Hasil penelitian ini menyatakan bahwa belum menguasai konsep ini secara utuh, karena masih salah dalam menghitung nilai kelarutan suatu senyawa dalam ion senama seperti (1) tidak mengalikan pangkat (2) tidak menggunakan ion unsur dari senyawanya yaitu sebesar $56 \%$. Hal ini disebabkan karena siswa tidak memahami konsep menentukan kelarutan dalam ion senama.

\section{Metode Penelitian}

Penelitian ini termasuk penelitian deskriptif yaitu jenis penelitian yang berhubungan dengan upaya menjawab masalah-masalah sekarang dan memaparkannya berdasarkan data yang ditemukan. Penelitian ini dilakukan uji coba soal sebagai alat ukur kesulitan siswa dalam memahami konsep pengaruh penambahan ion senama terhadap kelarutan, pada penelitian ini peneliti berusaha mendeskripsikan kesulitan siswa terhadap pemahaman konsep pengaruh penambahan ion senama terhadap kelarutan pada siswa kelas XI IPA SMA Negeri

3 Palangka Raya, SMA Negeri 4 Palangka Raya, SMA Negeri 5 Kota Palangka Raya Tahun Ajaran 2018/2019. Instrumen penelitian merupakan alat yang digunakan untuk menjaring data. Tes tertulis yang digunakan sebagai instrumen dalam penelitian ini dinamakan tes pemahaman materi ion senama dengan empat butir soal uraian didalamnya. Instrumen ini berupa soal uraian yang dibuat berdasarkan pengembangan indikator yang terdapat pada silabus Kurikulum 13 (K-13). Data kesulitan siswa dalam memahami konsep pengaruh penambahan ion 
senama terhadap kelarutan ditelusuri dengan cara memberikan tes tertulis berupa TPKIS yang terdiri atas empat butir soal. Semua data sebelum dianalisis dilakukan pengkodean, kemudian dianalisis disajikan seperti pada Tabel 1 berikut.

\section{Tabel 7. Analisis Data}

\section{Jenis Data}

\section{Teknik Analisis Data}

Data kesulitan siswa 1. Pemberian skor pada setiap butir soal pada hasil

yang ditelusuri pekerjaan siswa.

menggunakan

2. Dihitung persentase skor benar dengan persamaan

instrumen tes uraian. berikut.

\% skor benar

$$
=\frac{\sum \text { skor siswa yang menjawab benar }}{N \times \text { skor } \max } \times 100 \%
$$

3. Dihitung persentase kesulitan dengan persamaan berikut.

$\%$ kesulitan siswa $=100 \%-\%$ skor benar

4. Hasil perhitungan persentase kesulitan dikelompokkan sebagai berikut (Siwi, 2013) :

\begin{tabular}{cc}
\hline Kriteria & Persentase Kesulitan \\
\hline Tinggi & $61 \%-100 \%$ \\
\hline Sedang & $31 \%-61 \%$ \\
\hline Rendah & $0 \%-30 \%$ \\
\hline 5. Persentase kesulitan siswa dikelompokkan \\
berdasarkan asal sekolah.
\end{tabular}


6. Ditentukan pola kesulitan berdasarkan ragam pola jawaban siswa.

7. Perwakilan siswa yang mengalami kesulitan diwawancarai.

8. Setiap pola kesulitan hasil wawancara siswa dideskripsikan untuk menjelakan kesulitan yang dialami oleh siswa dalam menyelesaikan siswa.

\section{Hasil Penelitian Dan Pembahasan}

Hasil pengolahan data TPKIS kemudian di identifikasi dengan jumlah jawaban berdasarkan kategori jawaban. Secara keseluruhan didapatkan persentase kesulitan siswa berdasarkan kategori jawaban yang disajikan pada Tabel 1 berikut.

Tabel 1. Persentase Kesulitan Siswa pada SMA A, SMA B, dan SMA C Pada Setiap Konsep

\begin{tabular}{lcccc}
\hline \multirow{2}{*}{ Konsep } & \multicolumn{2}{c}{ Persentase Kesulitan per SMA(\%) } & \multirow{2}{*}{$\begin{array}{c}\text { Kesulitan } \\
\text { per Konsep }\end{array}$} \\
\cline { 2 - 4 } & SMA A & SMA B & SMA C & $53,29 \%$ \\
\hline $\begin{array}{l}\text { Pengaruh ion } \\
\text { senama terhadap } \\
\text { kelarutan }\end{array}$ & $52 \%$ & $54,28 \%$ & $53,89 \%$ & \\
\hline $\begin{array}{l}\text { Pengaruh } \\
\text { penambahan } \\
\text { garam yang sukar } \\
\text { larut terhadap } \\
\text { kelarutan garam } \\
\text { tersebut }\end{array}$ & $52 \%$ & $56,43 \%$ & $54,21 \%$ & $54,21 \%$ \\
\hline $\begin{array}{l}\text { Pengaruh } \\
\text { penambahan ion } \\
\text { senama dan air } \\
\text { murni terhadap } \\
\text { pengendapan }\end{array}$ & $55,33 \%$ & $54,29 \%$ & $56,84 \%$ & $56,84 \%$ \\
\hline \multicolumn{1}{c}{ Rata-rata } & $53,11 \% \%$ & $55 \%$ & $54,98 \%$ & $54,78 \%$ \\
\hline
\end{tabular}


Persentase kesulitan keseluruhan siswa pada setiap konsep dapat dilihat pada Gambar 1.

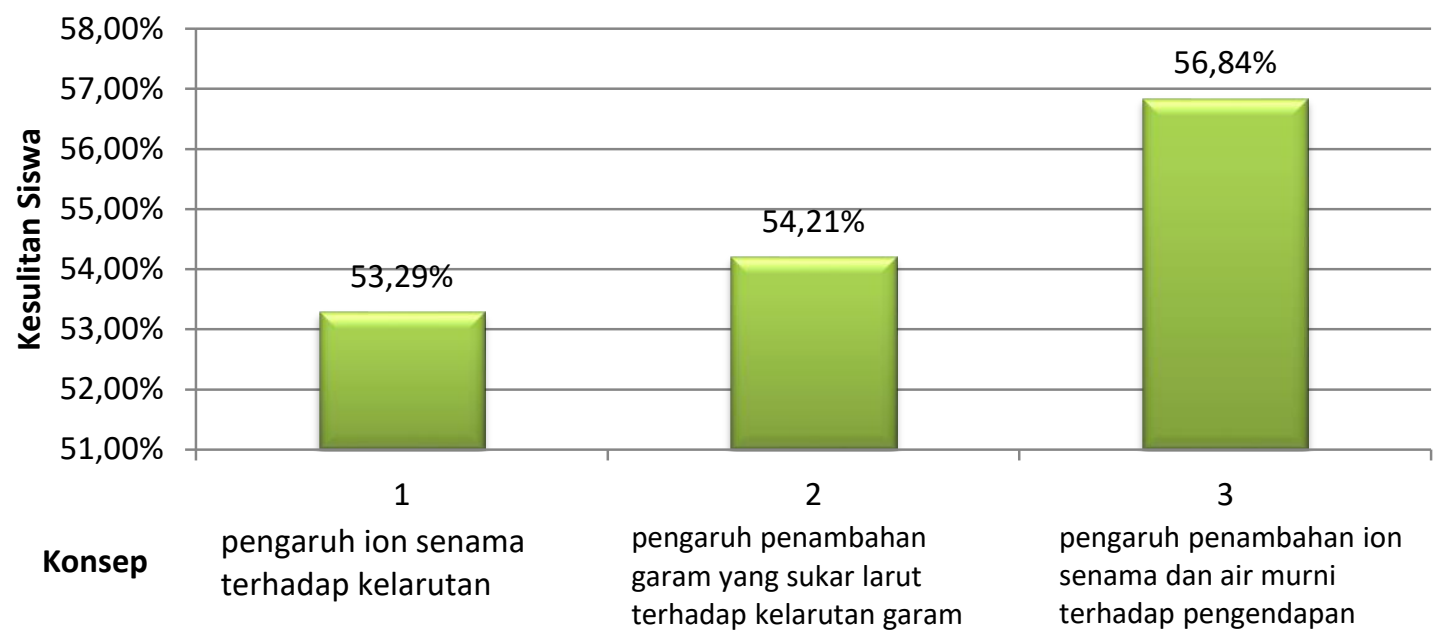

Gambar 1. Grafik Rerata Persentase Kesulitan Siswa Pada Setiap Konsep

Persentase kesulitan siswa dari setiap sekolah berdasarkan konsep dapat dilihat pada Gambar berikut.

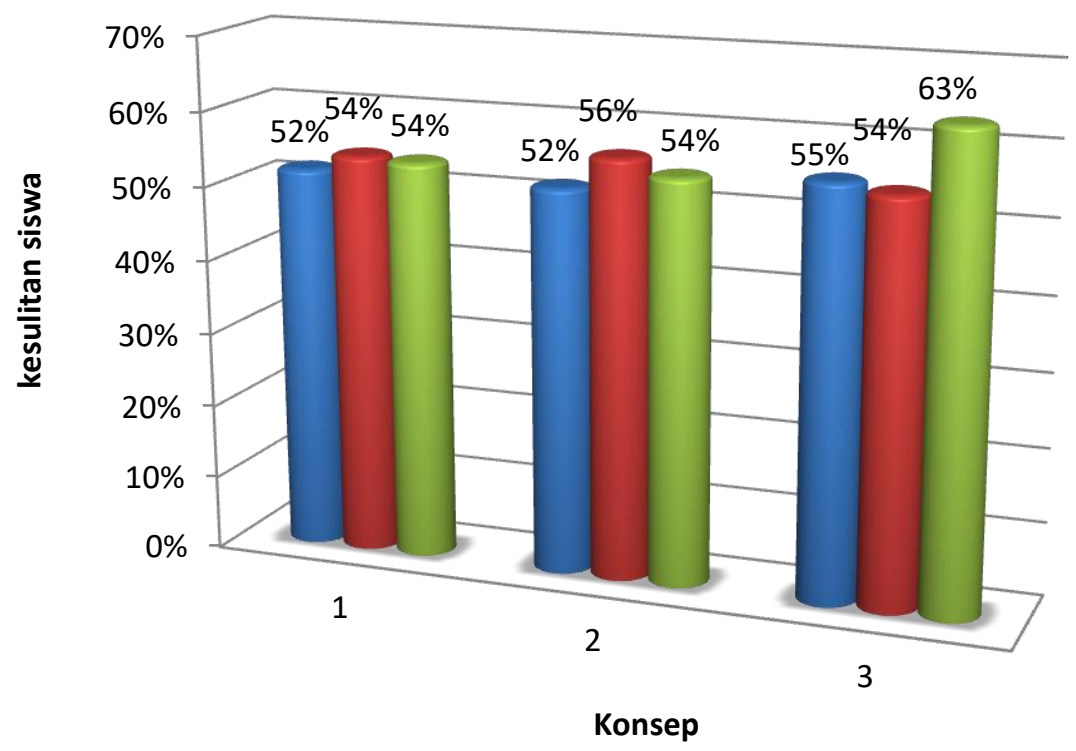

$\square$ Sekolah A

$\square$ Sekolah B

$\square$ Sekolah C

ket :

1. pengaruh ion senama terhadap kelarutan. 2. pengaruh penambahan garam yang sukar larut terhadap kelarutan garam. 3. pengaruh penambahan ion senama dan air murni terhadap pengendapan.

Gambar 2. Grafik Persentase Kesulitan Siswa Pada Setiap Sekolah SMA

Di Kota Palangka Raya 
Kesulitan siswa dalam menganalisis pengaruh penambahan ion senama ditelusuri dengan menggunakan instrumen TPKIS. Jumlah soal yang terkait dari konsep tersebut terdiri dari dua butir soal, yaitu soal nomor 1 dan 2. Melalui tes yang dilakukan, diperoleh rerata jumlah siswa yang mengalami kesulitan sebesar 53,29\%. Pola dominan kesulitan siswa adalah siswa mampu menentukan yang mengandung ion senama namun siswa kesulitan dalam menjelaskan pengertian penambahan ion senama. Pola jawaban siswa tersebut ditunjukkan pada Gambar 4

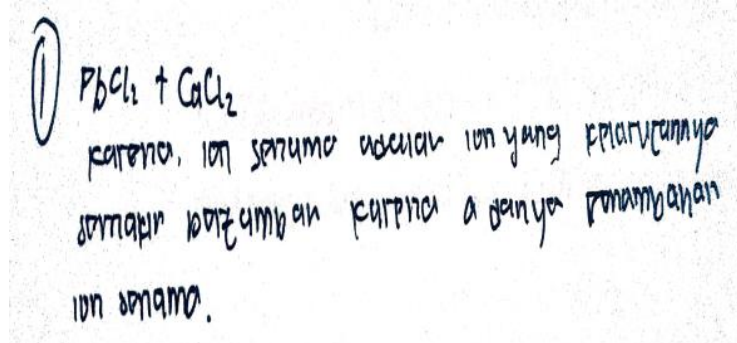

Gambar 3. Pola-1 Kesulitan Siswa Pada Butir Soal 1

satu, yaitu kesalahan siswa pada pola-1 (Gambar 3) kesulitan dalam menjelaskan pengertian penambahan ion senama tersebut. Dalam hal ini siswa mampu menentukan hasil pencampuran yang mengandung ion senama adalah $\mathrm{PbCl}_{2}$ dengan $\mathrm{CaCl}_{2}$, namun siswa mengalami kesulitan dalam menjelaskan pengertian penambahan ion senama, hal ini dikarenakan siswa beranggapan bahwa ion senama dapat menambah kelarutan tersebut, siswa juga mengatakan bahwa dalam kehidupan sehari-hari jika dilakukan penambahan secara terus menerus akan semakin bertambah

Pola dominan kesulitan siswa adalah siswa kesulitan dalam menjelaskan alasan pengaruh kelarutan $\mathrm{AgCl}$ setelah ditambahkan larutan $\mathrm{NaCl}$. Pola jawaban siswa tersebut ditunjukkan pada Gambar 4. 


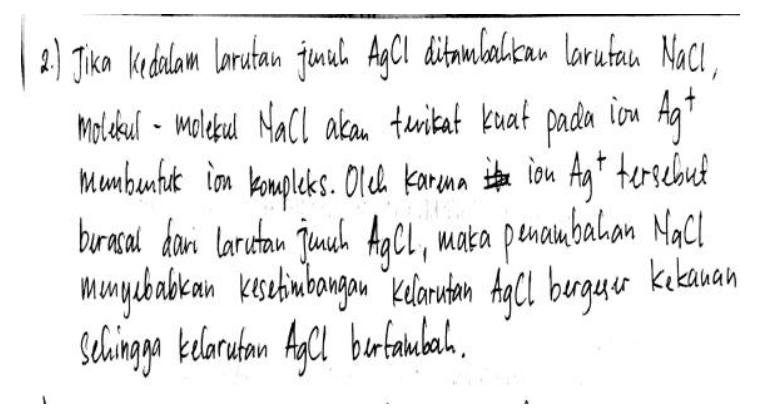

Gambar 4. Pola Kesulitan Siswa Pada Butir Soal 2

Gambar 4 menunjukkan pola dominan yang terjadi dengan siswa mengalami kesulitan dalam menentukan dan menjelaskan pengaruh kelarutan $\mathrm{AgCl}$ setelah ditambahkan larutan $\mathrm{NaCl}$. Kesulitan ini dikarenakan siswa beranggapan bahwa penambahan $\mathrm{NaCl}$ menyebabkan kesetimbangan kelarutan $\mathrm{AgCl}$ bergeser kekanan sehingga kelarutan $\mathrm{AgCl}$ bertambah. Siswa dapat memahami konsep kesetimbangan yaitu penambahan ion senama pada kesetimbangan akan menyebabkan konsentrasi ion bertambah sehingga kesetimbangan bergeser ke arah reaktan. Namun, siswa tidak memahami penambahan $\mathrm{NaCl}$ menyebabkan kesetimbangan kelarutan $\mathrm{AgCl}$ bergeser Ke kiri akibatnya kelarutan $\mathrm{AgCl}$ berkurang.

Kesulitan siswa dalam membandingkan pengaruh penambahan ion senama terhadap kelarutan asam dengan konsentrasi yang berbeda ditelusuri dengan menggunakan instrumen TPKIS. Soal yang terkait dari konsep tersebut terdapat pada butir soal 3. Melalui tes yang dilakukan, diperoleh rerata jumlah siswa yang mengalami kesulitan sebesar 54,21\%.

Pola dominan kesulitan siswa adalah siswa kesulitan dalam menjelaskan alasan larutan tersebut mudah larut. Pola kesalahan siswa tersebut ditunjukkan pada Gambar 5. 


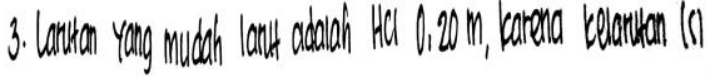

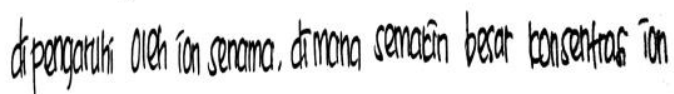

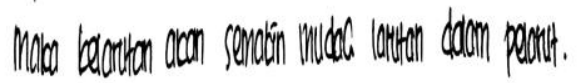

Gambar 5. Pola Kesulitan Siswa Pada Butir Soal 3

Gambar 5 menunjukkan pola dominan siswa kesulitan dalam menentukan dan menjelaskan larutan yang mudah larut. Berdasarkan pola jawaban, siswa menyatakan bahwa larutan yang mudah larut yaitu campuran $\mathrm{AgCl}$ dengan $\mathrm{HCl}$ 0,20 M. Siswa beranggapan bahwa semakin besar konsentrasi pelarut maka akan semakin mudah zat tersebut bereaksi atau mudah larut, siswa menyamakan akibat penambahan konsentrasi dengan pengaruh ion senama terhadap kelarutan.

Kesulitan siswa dalam membandingkan pengaruh penambahan ion senama dan air murni dalam larutan yang mudah larut ditelusuri dengan menggunakan instrumen TPKIS. Soal yang terkait dari konsep tersebut terdapat pada butir soal 4. Melalui tes yang dilakukan, diperoleh rerata jumlah siswa yang mengalami kesulitan sebesar 56,84\%.

Pola dominan kesulitan siswa adalah siswa mampu menentukan yang lebih banyak terbentuk endapan namun siswa kesulitan dalam menjelaskan alasan larutan yang lebih banyak terbentuk endapan. Pola kesalahan siswa tersebut ditunjukkan pada Gambar 6. 


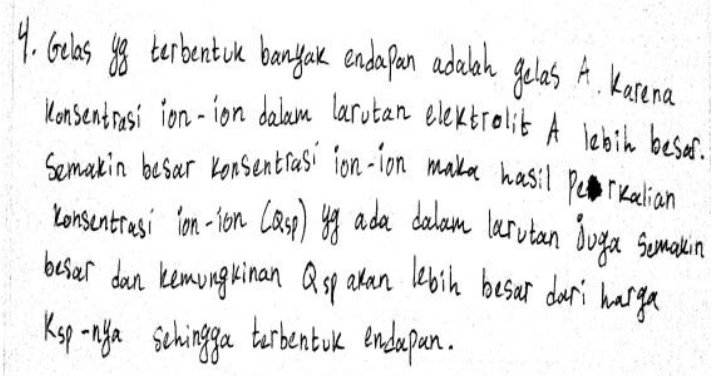

Gambar 6. Pola Kesulitan Siswa Pada Butir Soal 4

Gambar pola 6 pola kesalahan dominan yang terjadi dengan siswa kesulitan dalam menentukan dan menjelaskan larutan yang lebih banyak terbentuk endapan, siswa menjawab bahwa yang lebih banyak terbentuk endapan adalah gelas A yang berisi air murni dan siswa beranggapan bahwa konsentrasi ion-ion dalam larutan gelas A lebih besar, sehingga semakin besar konsentrasi ion maka hasil kali perkalian konsentrasi ion-ion (Qsp) yang ada dalam larutan juga akan semakin besar.

Berdasarkan hasil pola jawaban, siswa paham bahwa jika dilihat dari keadaan larutannya jika Qsp > Ksp akan terbentuk endapan. Tetapi siswa tidak paham bahwa pengendapan dapat terjadi pada sistem keadaan kesetimbangan, apabila pada kesetimbangan larutan jenuh garam sukar larut ditambah dengan larutan yang mengandung ion senama, maka ion senama akan menyebabkan konsentrasi ion garam bertambah. Jika konsentrasi ion garam sudah bertambah, maka sistem kesetimbangan bergeser kearah pembentukan garam untuk mengurangi kelebihan ion pada sistem kesetimbangan. Oleh karena larutan jenuh telah memiliki batas maksimum dalam melarut, maka penambahan garam karena pergeseran kesetimbangan menyebabkan terbentuknya endapan. 


\section{Simpulan}

Rerata persentase kesulitan siswa kelas XI IPA SMA Negeri Kota Palangka Raya dalam memahami konsep pengaruh penambahan ion senama terhadap kelarutan sebesar 54,78\%. Kesulitan siswa dalam memahami konsep pengaruh penambahan ion senama terhadap kelarutan, yaitu a) siswa menganggap jika ion senama ditambahkan ke dalam suatu larutan maka dapat menambah kelarutan dalam garam sukar larut. b) siswa menganggap jika semakin besar Qsp suatu larutan ion senama pada garam-garam yang memiliki jumlah ion yang sama, maka kelarutannya akan semakin kecil karena harga Ksp berbanding terbalik dengan harga kelarutan. Kesulitan yang dialami siswa dalam memahami konsep pengaruh penambahan ion senama terhadap kelarutan asam dengan konsentrasi yang berbeda adalah siswa menganggap bahwa penambahan ion senama terhadap kelarutan asam dengan konsentrasi yang berbeda semakin besar konsentrasi pelarut sehingga akan semakin mudah zat tersebut bereaksi atau mudah larut. Kesulitan yang dialami siswa dalam memahami konsep pengaruh penambahan ion senama dengan air murni dalam larutan yang mudah larut adalah siswa tidak memahami keadaan larutan jika sudah mengendap dan siswa tidak paham bahwa pengendapan dapat terjadi pada sistem kedaan kesetimbangan, apabila pada kesetimbangan larutan jenuh garam sukar larut ditambah dengan larutan yang mengandung ion senama, ion senama akan menyebabkan konsentrasi ion garam bertambah. 
Martauli Sibarani (201-214)

\section{Daftar Referensi}

Arianto, dkk. 2012. Deskripsi Pemahaman Konsep Siswa Pada Materi Kelarutan dan Hasil Kali Kelarutan Kelas XI IPA SMA. Pontianak: Program Studi Pendidikan Kimia FKIP Untan.

Arifin, M. 2007. Materi Pokok Pengembangan Kurikulum dan Pembelajaran Kimia. Jakarta: Universitas Terbuka.

Huzaifah, E. 2011. Upaya Meningkatkan Pemahaman Konsep Geometri Siswa Dengan Menggunakan Teori Van Hiele. Universitas Islam Negeri Syarif Hidayatullah. Jakarta.

Mirnayati, D. 2011. Identifikasi Tingkat Kesulitan Proses Belajar Praktik Membatik Siswa Kelas II Program Keahlian Kria Tekstil SMK Negeri 5 Yogyakarta. Yogyakarta: Terbitan Universitas Negeri Yogyakarta.

Sugihartono, dkk. 2007. Psikologi Pendidikan. Yogyakarta: UNY Press

Supranata, S. 2004. Analisis, Validitas, Reliabilitas dan Interpretasi Hasil Tes Implementasi Kurikulum 2004. Bandung: PT. Remaja Rosdakarya Offset.

Suwarto. 2013. Pengembangan Tes Diagnostik dalam Peembelajaran. Yogyakarta: pustaka Pelajar.

Viyandari, dkk. 2012. Analisis Konsepsi Siswa Terhadap Materi Kelarutan dan Hasil Kali Kelarutan (Ksp) dengan Menggunakan Two-Tier Diagnostic Instrument. Semarang: Jurusan Kimia FMIPA Universitas Negeri Semarang. 